\section{The Effect of Salinity on the Growth and Nutrient Status of Zinnia Grown Under Short- and Long-cycle Subirrigation Management}

\author{
Kranti Macherla ${ }^{1}$ and Richard J. McAvoy ${ }^{1}$ \\ Department of Plant Science and Landscape Architecture, University of \\ Connecticut, Storrs, CT 06269
}

Additional index words. salinity, irrigation, fertilizer

\begin{abstract}
As water resources become limited, agricultural producers must resort to alternative sources for irrigation, including municipal reclaimed water which may contain impurities such as salts that can adversely impact irrigation management practices and crop yield. To test the effects of salinity on plant growth and nutrient composition under greenhouse conditions, zinnia (Zinnia elegans) was produced under two different subirrigation management regimes and exposed to various concentrations of $\mathrm{NaCl}$ to simulate the crop production challenges associated with poor water quality. Plants received either short- or long-cycle subirrigation to achieve differing levels of potting medium saturation at each irrigation event. Plants under these two irrigation management regimes were challenged with $\mathrm{NaCl}$ at concentrations up to $1.5 \mathrm{~g} \cdot \mathrm{L}^{-1}$ or $3 \mathrm{dS} \cdot \mathrm{m}^{-1}$. Zinnia plants accumulated more $\mathrm{Na}$ in shoot tissues as salinity in the irrigation water increased from 0 to $1.5 \mathrm{~g} \cdot \mathrm{L}^{-1}$. The electrical conductivity (EC) in the potting medium also increased over time, and the rate of leaf area expansion decreased with increasing levels of salinity in the irrigation water. Short-cycle irrigation management has been shown to increase fertilizer and water use efficiency (WUE), thereby reducing the costs associated with these resources and also reducing the environmental impacts of agricultural crop production. In our study, the medium under short-cycle subirrigation management had lower gravimetric water content (GWC), both before and after irrigation, than the medium under long-cycle subirrigation, but the drier medium conditions did not increase susceptibility to salt injury. Furthermore, plants grown under short-cycle irrigation management for 4 to 6 weeks accumulated less $\mathrm{Na}$ in shoot tissue than plants grown under long-cycle irrigation management. Sodium accumulation in the shoot tissues was a product of both the amount of sodium in the irrigation solution and the amount of water used by the plant over time. Therefore, short-cycle subirrigation can be used as an effective water management technique even when raw water quality is poor as represented by elevated salinity. Our research indicates that zinnia can be irrigated with saline water up to $0.5 \mathrm{~g} \cdot \mathrm{L}^{-1} \mathrm{NaCl}\left(\right.$ an $\mathrm{EC}$ of $1 \mathrm{dS} \cdot \mathrm{m}^{-1}$ ) in a 5 -week production cycle without adverse effects on growth.
\end{abstract}

Water is essential for agricultural crop production, but globally, the availability of water of acceptable quality is increasingly becoming a limited resource. Irrigated agriculture is one of the largest yet most inefficient users of this resource. As population increases, competition for fresh water between civil uses and agriculture will only increase. Therefore, agricultural producers

\footnotetext{
Received for publication 22 Nov. 2016. Accepted for publication 21 Mar. 2017.

This project was supported, in part, by the USDA National Institute of Food and Agriculture, Hatch Multistate Accession Number 1001659, project no. CONS00918.

We thank Joseph Geremia of Geremia Greenhouse and George Elliott of the University of Connecticut, who contributed all the plant material and equipment used in this study. Joel Tilley of the University of Vermont contributed technical help for the analysis of samples.

${ }^{1}$ Corresponding authors. E-mail: kranti.macherla@ uconn.edu or richard.mcavoy@uconn.edu.
}

will need to adapt to using alternative irrigation sources such as municipal reclaimed water that may contain elevated levels of impurities such as $\mathrm{Na}$, and also adopt new irrigation and cultivation practices that maintain high productivity but with a greater WUE.

Greenhouse crop production is an intensive form of agriculture with high crop production rates and equally high fertilizer and water consumption. Greenhouse systems also enable producers to use sophisticated irrigation techniques to maximize water and fertilizer use efficiency. The most efficient systems deliver water directly to each plant and capture and reuse runoff. In closed subirrigation systems such as those used in controlled-environment agricultural production for example, water is taken up by capillary action through the base of the production container, and unused water is drained back into a reservoir for reuse. Water management within these systems further affects WUE and crop quality. In these subirrigation systems, the production surface, typically impervious benches or floors, is flooded up to a depth of $2 \mathrm{~cm}$. Subirrigation management reduces fertilizer use by $30 \%$ to $40 \%$ (Strefeler, 1991). A modified subirrigation watering system was developed by Geremia Greenhouse (Wallingford, CT) in collaboration with TrueLeaf Technologies (Petaluma, CA). This system allows growers to limit the duration of subirrigation to a shortcycle (Gent and McAvoy, 2011), and thus, limit the degree of medium saturation. This method of watering has been referred to as short-cycle subirrigation management or partial-saturation irrigation (Gent and McAvoy, 2011). Short-cycle subirrigation is a process where the GWC of the medium is regulated by limiting the contact time between the container and the irrigation solution. In this management system, medium saturation does not reach full capacity at each irrigation event. Containers under short-cycle subirrigation management may take in $25 \%$ less water than those under long-cycle subirrigation, and the incidence of root rot disease is reduced significantly compared with crops produced under irrigation management practices that allow the potting medium to approach full saturation (Elmer et al., 2012). Under short-cycle subirrigation, growers have more control over crop growth, especially stem elongation, so that ornamental plants develop the compact stature most desired by the industry and accumulate less biomass (Gent and McAvoy, 2011).

The uptake of water by the plant is measured in terms of volumetric water content or GWC (Gent and McAvoy, 2011). GWC is defined by the following equation:

GWC = In situ weight of the potting container - oven dry weight

$\overline{T o t a l}$ container volume(g. equivalent of water)

GWC can be determined before and after irrigation as follows:

GWC before irrigation

$=$ Weight of the potting container before irrigation - oven dry weight

$\overline{\text { Total container volume(g. equivalent of water) }}$

GWC after irrigation

$=$ Weight of the potting container after irrigation - oven dry weight

$\overline{\text { Total container volume(g. equivalent of water) }}$

The physico-chemical properties of a growing medium, determined by the material composition of the medium, have major effects on plant growth. These factors include water-holding capacity, cation-exchange capacity, $\mathrm{pH}$, and EC. Most commercial growing media used in greenhouse production contain sphagnum moss, vermiculite, perlite, 
or bark in various proportions. More recently, other amendments such as coconut coir, rice hulls, and wood fibers have been tested for efficacy as media amendments. Coir-amended mixes have higher moisture-holding capacity than peat-based mixes (Stamps and Evans, 1997).

As no leaching occurs in subirrigation, excess salts from fertilizer and contaminants in the irrigation water such as salinity accumulate in the potting medium resulting in elevated EC (Argo and Biernbaum, 1996; van Iersel, 2000), a phenomenon that is similar to salt crusting observed in arid regions. The accumulation of salts can be a concern when raw water quality is low or when an alternate source of irrigation water carries unwanted ions. How such circumstances might affect greenhouse crop performance under shortcycle subirrigation, where the water available to the plant is restricted, has not been reported. Therefore, the focus of this research was to determine the effect of $\mathrm{NaCl}$ on the growth and nutrient composition of zinnia grown under different subirrigation management regimes.

Zinnia elegans, a species previously identified as salinity sensitive (Villarino and Mattson, 2011), was selected as the test crop in this study.

\section{Materials and Methods}

Two experiments were conducted to determine the effect of $\mathrm{NaCl}$ on the growth and nutrient composition of the zinnia (Zinnia elegans) cultivar 'Dreamland'.

Zinnia growth under short-and long-cycle irrigation, with or without supplemental $\mathrm{NaCl}$. For the first experiment, zinnia plugs (512 cell trays) were obtained from a commercial propagator (Geremia Greenhouse, Wallingford, CT). Plugs were transplanted, one per pot, into a blend of coconut coir and Fafard 3B (Sun Gro Horticulture Canada Ltd.) at a 3:1 ratio in 12-cm containers (X-4PXD Extra Deep Square Pot with root channel; Landmark Plastics, Akron, OH). The potting containers were placed in troughs of $107 \times 28$ $\mathrm{cm}$ in size. Each trough, representing a single treatment combination, contained five plants, and each bench had four troughs. The treatment combinations were short- or long-cycle subirrigation at each irrigation event, using an irrigation solution containing either 0 or $1.5 \mathrm{~g} \cdot \mathrm{L}^{-1} \mathrm{NaCl}$. There were three replicates for each treatment and fifteen plants for each combination. Plants were watered when the weight of the plant and medium dropped to one-third of the irrigated weight under shortor long-cycle irrigation, respectively. The total irrigation cycle was 4 min for shortcycle and $15 \mathrm{~min}$ for long-cycle with the contact period between the base of the container and the irrigation solution being 3 and $14 \mathrm{~min}$, respectively. The standard fertilizer solution for all treatments was a solution containing $20 \mathrm{~N}-4.3 \mathrm{P}-16.6 \mathrm{~K}$ peat-lite (J.R. Peters, Inc., Allentown, PA) at the rate $0.1 \mathrm{~g} \cdot \mathrm{L}^{-1}$ water $\left(20 \mathrm{mg} \cdot \mathrm{L}^{-1} \mathrm{~N}\right)$ and $15 \mathrm{~N}-0 \mathrm{P}$ $10.8 \mathrm{~K}$ (J.R. Peters, Inc.) at the rate $0.2 \mathrm{~g} \cdot \mathrm{L}^{-1}$ water $\left(30 \mathrm{mg} \cdot \mathrm{L}^{-1} \mathrm{~N}\right)$. Treatments started as soon as the roots on the newly transplanted plugs reached the sides of the potting container. Plants were weighed before and after each irrigation event, and the GWC was calculated. Plants received treatments for 8 weeks starting on 28 May and continuing until 23 July 2013. Day temperatures in the greenhouse averaged $22{ }^{\circ} \mathrm{C}$, and night temperatures averaged $16{ }^{\circ} \mathrm{C}$ during this period.

A single plant from each treatment combination (in each replicate) was harvested at weeks $2,4,6$, and 7, and the length of the main stem, number of nodes, and plant height were recorded. The length of the main stem and number of nodes were used to calculate the average internode length for each plant. The shoot tissue was oven-dried at $75^{\circ} \mathrm{C}$ for $72 \mathrm{~h}$. The dried shoot tissue of the plants harvested from weeks 4 through 6 were ground and analyzed for nutrient composition. For each tissue sample, $200 \mathrm{mg}$ of oven-dried and ground tissue was placed in a $20 \mathrm{~mL}$ scintillation vial and weighed to the nearest milligram. The samples were placed in a muffle furnace at $500-550{ }^{\circ} \mathrm{C}$ for $4-6 \mathrm{~h}$, and the resulting ash was cooled for $1 \mathrm{~h}$. A measured volume $(20 \mathrm{~mL})$ of $0.2 \mathrm{~N} \mathrm{HCl}$ was added to each sample, and samples were analyzed using the Spectro Ciros Vision ICP-OES (Spectro, Mahwah, NJ).

Chlorophyll from fresh leaf samples was extracted in $\mathrm{N}, \mathrm{N}$-dimethyformamide and the concentration determined according to Inskeep and Bloom (1985). Leaf samples were collected from the youngest fully mature leaf on each sample plant, using a cork borer to remove a $0.9 \mathrm{~cm}^{2}$ disc. These samples were incubated at room temperature in complete darkness, and after $24 \mathrm{~h}$, total chlorophyll concentrations were determined by using a spectrophotometer (Spectronic GENESYS 5; Madison, WI) at 647 and $664.5 \mathrm{~nm}$ using the following formula (Inskeep and Bloom, 1985):

Total chlorophyll $=17.90 \mathrm{~A}_{647}+8.08 \mathrm{~A}_{664.5}$

where $\mathrm{A}=$ absorbance in 1-cm cuvettes.

Zinnia growth under varying concentrations of $\mathrm{NaCl}$. In a second study, seeds of the zinnia cultivar 'Dreamland' were sown into 200 cell plug trays, and after 3 weeks, plugs were transplanted into $12-\mathrm{cm}$ containers as previously described. The medium used was a blend of coconut coir and Fafard 3B at a 3:1 ratio. The containers were placed in $107 \times 28 \mathrm{~cm}$ troughs, with 10 containers per trough. Plants were irrigated to short-cycle using a 4-min subirrigation cycle. At each irrigation event, plants would receive the standard fertilizer solution as previously described, along with $\mathrm{NaCl}$ at one of the following concentrations: $0,0.3,0.6,0.9$, 1.2 , or $1.5 \mathrm{~g} \cdot \mathrm{L}^{-1}$, equivalent to $\mathrm{EC}$ of $0.6,1.2$, $1.8,2.4$, or $3.0 \mathrm{dS} \cdot \mathrm{m}^{-1}$, respectively. There were four replications. Treatments were applied for 5 weeks starting from 5 Oct. 2013. Day temperatures in the greenhouse averaged $23{ }^{\circ} \mathrm{C}$, and night temperatures averaged $18{ }^{\circ} \mathrm{C}$. Plants were weighed before and after each irrigation event, and the GWC was calculated (Gent and McAvoy, 2011).

A sample plant was harvested from each replicated treatment at weekly intervals, and the total leaf area was recorded. Tissue samples were ovendried at $75^{\circ} \mathrm{C}$ for at least $72 \mathrm{~h}$. The potting medium for each individually sampled plant was dried, and the EC was determined using an EC meter (Hanna Instruments, Woonsocket, RI). The dried potting medium and the shoot tissue samples were analyzed for nutrient composition as previously described.

Experimental design and statistics. For the first experiment, treatments were arranged in a split plot design with the main plot arranged in a randomized complete block design with three replications. The treatment combinations were short- or long-cycle subirrigation with or without the addition of $\mathrm{NaCl}$. The main plot was salinity treatment; the subplot was length of irrigation cycle. Analysis of variance was used to determine treatment effects on plant growth, tissue nutrient content, and EC of the potting medium.

For the second experiment, treatments were arranged in a randomized complete block design with four replications. Analysis of variance was used to determine treatment effects on plant growth, tissue nutrient composition, medium nutrient composition, and $\mathrm{EC}$ of the potting medium.

\section{Results}

Water uptake and plant growth in zinnia grown with or without addition of $\mathrm{NaCl}$. Plants irrigated by a long-cycle had greater GWC than plants irrigated by a short-cycle, both before and after irrigation (Table 1). Plants treated with $\mathrm{NaCl}$ treatment had lower dry weights and less chlorophyll per unit leaf area compared with plants not exposed to supplemental $\mathrm{NaCl}$ (Table 1). Plants exposed to supplemental $\mathrm{NaCl}$ were shorter than those not exposed to elevated salinity, and the shorter plants also developed shorter internodes (Table 1). Irrigation management had no significant effect on any of the parameters measured except GWC.

Nutrient composition in the shoot tissue of zinnia grown with or without addition of $\mathrm{NaCl}$. Plants exposed to elevated salinity contained higher concentrations of $\mathrm{P}, \mathrm{K}, \mathrm{Ca}$, and $\mathrm{Mn}$ in shoot tissue than plants not exposed to the supplemental $\mathrm{NaCl}$ treatment, but lower concentrations of $\mathrm{Al}$ and $\mathrm{Fe}$ (Table 2). Tissue $\mathrm{Na}$ content was most dramatically affected by salinity in the irrigation water with an average shoot tissue concentration of $0.9 \% \quad(>9000$ $\mathrm{mg} \cdot \mathrm{L}^{-1}$ ) over weeks 4 to 6 in subirrigation. In this study, irrigation management had no effect on tissue nutrient content with the exception of $\mathrm{Na}$. Here, zinnia produced under long-cycle subirrigation accumulated over $35 \%$ more $\mathrm{Na}$ 
Table 1. The effects of $\mathrm{NaCl}$ and irrigation management on zinnia water uptake and growth. Data represent the values at final harvest. Gravimetric water content (GWC) of the potting medium was recorded before and after each irrigation event.

\begin{tabular}{|c|c|c|c|c|c|c|}
\hline Treatment & GWC before $\left(\mathrm{g} \cdot \mathrm{g}^{-1}\right)$ & GWC after $\left(\mathrm{g} \cdot \mathrm{g}^{-1}\right)$ & Internode length $(\mathrm{cm})$ & Dry wt (g) & Plant ht $(\mathrm{cm})$ & Chlorophyll concn $\left(\mathrm{mg} \cdot \mathrm{cm}^{-2}\right)$ \\
\hline $0 \mathrm{~g} \cdot \mathrm{L}^{-1}$ & 0.09 & 0.32 & 3.6 & 4.1 & 29 & 0.028 \\
\hline \multicolumn{7}{|l|}{ Irrigation (I) } \\
\hline Long-cycle & 0.12 & 0.35 & 3.1 & 3.4 & 25 & 0.023 \\
\hline \multicolumn{7}{|l|}{ Significance } \\
\hline Salinity & $* * *$ & NS & ** & ** & $* * *$ & ** \\
\hline
\end{tabular}

**, ***, and NS denote significance at $P \leq 0.01, P \leq 0.001$ levels, and not significant, respectively.

Table 2. Average nutrient composition in the shoot tissue at 4- and 6-week harvest of zinnia plants grown with or without the addition of $1.5 \mathrm{~g} \cdot \mathrm{L}^{-1}$ $\mathrm{NaCl}$.

\begin{tabular}{|c|c|c|c|c|c|c|c|}
\hline \multirow[b]{2}{*}{ Treatment } & $\mathrm{P}$ & $\mathrm{K}$ & $\mathrm{Ca}$ & $\mathrm{Na}$ & $\mathrm{Al}$ & $\mathrm{Fe}$ & Mn \\
\hline & \multicolumn{3}{|c|}{$\left(\mathrm{g} \cdot \mathrm{kg}^{-1}\right)$} & \multicolumn{4}{|c|}{$\left(\mathrm{mg} \cdot \mathrm{kg}^{-1}\right)$} \\
\hline \multicolumn{8}{|l|}{ Salinity (S) } \\
\hline $1.5 \mathrm{~g} \cdot \mathrm{L}^{-1}$ & 3.6 & 63 & 8.2 & 9,012 & 12 & 49 & 81 \\
\hline $0 \mathrm{~g} \cdot \mathrm{L}^{-1}$ & 3.0 & 53 & 5.7 & 564 & 16 & 62 & 56 \\
\hline \multicolumn{8}{|l|}{ Irrigation (I) } \\
\hline Short & 3.2 & 58 & 6.9 & 4,066 & 13 & 55 & 69 \\
\hline Long & 3.3 & 57 & 7.0 & 5,510 & 15 & 56 & 68 \\
\hline \multicolumn{8}{|l|}{ Significance } \\
\hline Salinity & * & * & $* * *$ & $* *$ & $* * *$ & $*$ & $*$ \\
\hline Irrigation & NS & NS & NS & $*$ & NS & NS & NS \\
\hline S*I & NS & NS & NS & $*$ & NS & NS & NS \\
\hline
\end{tabular}

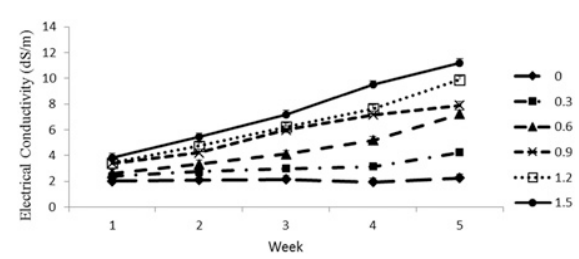

Fig. 1. Electrical conductivity of the potting medium over a 5-week production cycle for zinnia grown under subirrigation with a nutrient solution containing $\mathrm{NaCl}$ at $0,0.3,0.6,0.9,1.2$, or $1.5 \mathrm{~g} \cdot \mathrm{L}^{-1}$. Bars represent standard errors.

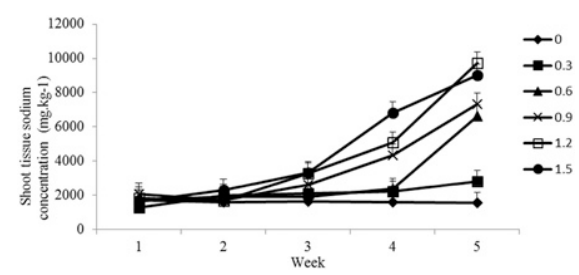

Fig. 2. Sodium concentration in the shoot tissue over a 5-week production cycle for zinnia grown under subirrigation with a nutrient solution containing $\mathrm{NaCl}$ at $0,0.3,0.6,0.9,1.2$, or $1.5 \mathrm{~g} \cdot \mathrm{L}^{-1}$. Bars represent standard errors. Sodium accumulation in the shoot tissue increased with increased concentration of sodium in nutrient solution.

in shoot tissue than under short-cycle subirrigation.

Plant growth in zinnia grown under varying concentrations of $\mathrm{NaCl}$. As salinity levels in nutrient solution increased, both EC of the potting medium (Fig. 1) and $\mathrm{Na}$ accumulation in the shoot tissue increased (Fig. 2).

Salinity affected leaf area in all treatment groups. The rate of increase in leaf area decreased as salinity levels in the nutrient solution increased $(P \leq 0.05)$. The average rate of increase in leaf area from week 1 to 5 was $4.0,5.7,4.9,4.6,1.9$, and $1.9 \mathrm{~cm}^{2} \cdot \mathrm{d}^{-1}$ for plant exposed to $\mathrm{NaCl}$ concentrations of $0,0.3,0.6,0.9,1.2$, and $1.5 \mathrm{~g} \cdot \mathrm{L}^{-1}$, respectively. The average leaf area recorded in the $1.5 \mathrm{~g} \cdot \mathrm{L}^{-1} \mathrm{NaCl}$ treatment dropped in the final week as the plants in this treatment developed significant water stress symptoms including leaf tissue damage, in association with excessive accumulation of $\mathrm{Na}$ in the potting medium and the plant tissues (Fig. 3).

At the end of week 5, plants exposed to the highest concentrations of salinity showed severe leaf injury and general water stress symptoms (Fig. 3). Leaf damage and adverse effects on growth were visibly evident on plants exposed to $\mathrm{Na}$ at $0.9 \mathrm{~g} \cdot \mathrm{L}^{-1}$ or higher. This damage coincided with tissue $\mathrm{Na}$ concentrations over $6000 \mathrm{mg} \cdot \mathrm{L}^{-1}$ and potting medium EC over $6 \mathrm{dS} \cdot \mathrm{cm}^{-1}$. Plants exposed to the highest $\mathrm{Na}$ concentrations began to show visible water stress and leaf damage after 4 weeks exposure to supplemental $\mathrm{Na}$.

Nutrient composition in the shoot tissue of zinnia grown under varying concentrations of $\mathrm{NaCl}$. A linear correlation between $\mathrm{Na}$ concentration in the irrigation solution and shoot tissue accumulation of $\mathrm{K}, \mathrm{Ca}, \mathrm{Mg}$, $\mathrm{Mn}, \mathrm{Zn}$, and $\mathrm{Na}$ (Table 3) was observed. Sodium accumulation in the shoot tissue increased with the increase in $\mathrm{Na}$ concentration in the nutrient solution from 0 to $1.2 \mathrm{~g} \cdot \mathrm{L}^{-1}$. Sodium concentration at final harvest in plants treated with $1.5 \mathrm{~g} \cdot \mathrm{L}^{-1} \mathrm{NaCl}$ was less than in plants exposed to $1.2 \mathrm{~g} \cdot \mathrm{L}^{-1}$, as plants treated with $1.5 \mathrm{~g} \cdot \mathrm{L}^{-1} \mathrm{NaCl}$ developed leaf damage and symptoms of water stress earlier in the crop cycle which resulted in lower water uptake and reduced $\mathrm{Na}$ accumulation over the final weeks of the study.

\section{Discussion}

Plants grown in agricultural systems are subjected to environmental stress from many sources, all of which have the potential to limit growth and development. With over $50 \%$ of arable land expected to be affected by salinity by 2050 (Vinocur and Altman, 2005), plant resistance to abiotic and biotic stresses such as drought and salinity has the potential to mitigate the impact on crop production under such conditions (Epstein, 1999). Suppression of plant growth under saline conditions may be because of the toxicity of $\mathrm{NaCl}$ or decrease in the availability of water (Munns, 2002). Salinity inhibits the expansion of leaf surface, thereby decreasing fresh and dry weight of leaves (Takemura et al., 2000). Our study shows similar results with plants exposed to continuous irrigation with $1.5 \mathrm{~g} \cdot \mathrm{L}^{-1} \mathrm{NaCl}$ having lower dry weight, shorter internode length and plant height, and lower chlorophyll concentration compared with plants not exposed to $\mathrm{NaCl}$ (Table 1 ). When plants were treated with varying concentrations of salinity, the rate of increase in leaf area from week 1 to 5 decreased as $\mathrm{Na}$ concentration in the nutrient solution increased.

Increase in salinity can cause severe chemical deficiencies in plants (Khan et al., 2000). Neto et al. (2012) reported that increased $\mathrm{Na}$ and $\mathrm{Cl}$ accumulation in leaves affected the uptake of other nutrients such as K and Ca. Miranda et al. (2007) reported that salinity causes a decrease in Ca concentration in Moringa oleifera. Neto et al. (2012) reported a decrease in $\mathrm{Mg}$ concentration under saline conditions in castor bean.

In our study, plants treated with $1.5 \mathrm{~g} \cdot \mathrm{L}^{-1}$ $\mathrm{NaCl}$ accumulated more $\mathrm{P}, \mathrm{K}, \mathrm{Ca}, \mathrm{Na}$, and $\mathrm{Mn}$ and less $\mathrm{Al}$ in the shoot tissue (per gram of dry weight) than plants not supplemented with additional $\mathrm{NaCl}$ (Table 2). As salinity levels increase, leaf $\mathrm{Na}^{+}$and $\mathrm{Cl}^{-}$content tend to increase in bedding plants (Niu et al., 2010). In our study, increasing levels of salinity from 0 to $1.5 \mathrm{~g} \cdot \mathrm{L}^{-1}$ at $0.3 \mathrm{~g} \cdot \mathrm{L}^{-1}$ increments resulted in $\mathrm{Na}$ concentration in zinnia shoot tissue that increased linearly over time of exposure from week 1 to 5 . This increase in tissue accumulation of $\mathrm{Na}$ simultaneously coincided with a similar increase in EC in the potting medium (Figs. 1 and 2).

Water uptake in containers under shortcycle management is lower than in containers under long-cycle subirrigation management (Gent and McAvoy, 2011). In our study, containers under short-cycle management 


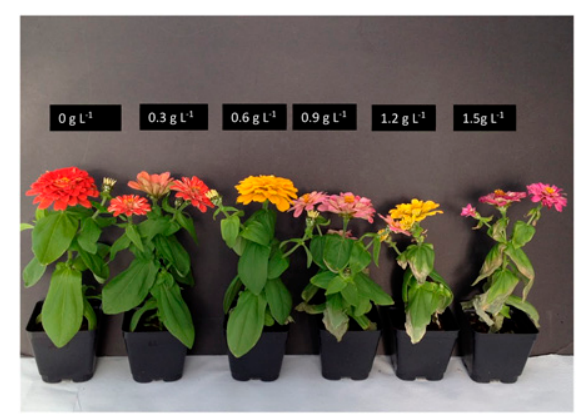

Fig. 3. Physical appearance at week 5 of zinnia plants grown under subirrigation with a nutrient solution containing $\mathrm{NaCl}$ at $0,0.3,0.6,0.9,1.2$, or $1.5 \mathrm{~g} \cdot \mathrm{L}^{-1}$.

Table 3. Final nutrient composition in the shoot tissue for zinnia grown under subirrigation with a nutrient solution containing $\mathrm{NaCl}$ at $0,0.3$, $0.6,0.9,1.2$, or $1.5 \mathrm{~g} \cdot \mathrm{L}^{-1}$.

\begin{tabular}{|c|c|c|c|c|c|c|}
\hline & $\mathrm{K}$ & $\mathrm{Ca}$ & $\mathrm{Mg}$ & $\mathrm{Mn}$ & $\mathrm{Zn}$ & $\mathrm{Na}$ \\
\hline & \multicolumn{3}{|c|}{$\left(\mathrm{g} \cdot \mathrm{kg}^{-1}\right)$} & \multicolumn{3}{|c|}{$\left(\mathrm{mg} \cdot \mathrm{kg}^{-1}\right)$} \\
\hline \multicolumn{7}{|l|}{ Treatment } \\
\hline $0 \mathrm{~g} \cdot \mathrm{L}^{-1}$ & 49 & 5.4 & 5.5 & 38.5 & 36 & 1,537 \\
\hline $0.3 \mathrm{~g} \cdot \mathrm{L}^{-1}$ & 49 & 6.7 & 7.2 & 31.5 & 41 & 2,825 \\
\hline $0.6 \mathrm{~g} \cdot \mathrm{L}^{-1}$ & 51 & 7.0 & 6.4 & 36.2 & 37 & 6,637 \\
\hline $0.9 \mathrm{~g} \cdot \mathrm{L}^{-1}$ & 56 & 7.3 & 7.1 & 50.6 & 41 & 7,335 \\
\hline $1.2 \mathrm{~g} \cdot \mathrm{L}^{-1}$ & 55 & 7.4 & 7.1 & 62.5 & 44 & 9,732 \\
\hline $1.5 \mathrm{~g} \cdot \mathrm{L}^{-1}$ & 57 & 7.3 & 7.2 & 67.7 & 50 & 9,027 \\
\hline \multicolumn{7}{|l|}{ Significance } \\
\hline Linear & $* *$ & ** & ** & $* * *$ & $* *$ & $* * *$ \\
\hline Quadratic & NS & NS & NS & $*$ & NS & NS \\
\hline Cubic & NS & NS & NS & $*$ & NS & NS \\
\hline
\end{tabular}

had lower GWC both before and after irrigation than containers under long-cycle management irrespective of salinity treatments (Table 1).

Here, we report that leaf area was the first indicator of increasing salt stress in zinnia. The rate of leaf area expansion began to decline around week 4 with increasing levels of salinity and coincided with a simultaneous increase in EC of the potting medium. Even though plants produced under short-cycle irrigation developed under restricted water availability, exposure to elevated salinity was not more damaging to these plants. In fact, tissue accumulation of $\mathrm{Na}$ under long-cycle management was over $35 \%$ higher than in plants under short-cycle irrigation when both were exposed to the same salinity concentration. Previous studies on restricted irrigation management demonstrated greater WUE (Gent and McAvoy, 2011). Here, we found that $\mathrm{Na}$ accumulation in the medium was directly related to the total irrigation solution taken up over time, and tissue accumulation of $\mathrm{Na}$ in zinnia tracked closely to $\mathrm{Na}$ accumulation in the potting medium. Therefore, short-cycle irrigation management can be used as an effective water management technique even when raw water quality is poor as represented by elevated salinity and may be even more advantageous as the duration of the cropping cycle increases.

\section{Literature Cited}

Argo, W.R. and J.A. Biernbaum. 1996. Availability and persistence of macronutrients from lime and pre-plant nutrient charge fertilizers in peatbased root media. J. Amer. Soc. Hort. Sci. 121:453-460.

Elmer, W.H., M.P.N. Gent, and R.J. McAvoy. 2012. Partial saturation under Ebb and Flow irrigation suppresses Pythium root rot of ornamentals. Crop Prot. 33:29-33.

Epstein, E. 1999. Solution culture techniques, p. 207-245. In: Y. Hashimoto, P.J. Kramer, H. Nomani, and B.R. Strain (eds.). Measurement techniques in plant sciences. Academic Press Inc., San Diego, CA.

Gent, M.P.N. and R.J. McAvoy. 2011. Water and nutrient uptake and use efficiency with partial saturation Ebb and Flow watering. HortScience $46: 1-8$.

Inskeep, W.P. and P.R. Bloom. 1985. Extinction coefficients of chlorophyll $\mathrm{a}$ and $\mathrm{b}$ in $\mathrm{N}$,
N-Dimethylformamide and $80 \%$ acetone. Plant Physiol. 77:483-485.

Khan, M.A., I.A. Ungar, and A.M. Showalter. 2000. Effects of salinity on growth, water relations and ion accumulation of the subtropical perennial halophyte, Atriplex griffithiivar, stocksii. Ann. Bot 86(2):225-232.

Miranda, J.R.P., J.G.C. Carvalho, A.R. Fernandez, and H.N. Paiva. 2007. Producao de biomassa seca e acumulo de nutrients e Na por plantas de moringa (Moringa oleifera Lam.) cultivadas em solucao nutritive com differentes niveis de $\mathrm{NaCl}$. Rev. Cienc. Agrar. (Belem.) 47:187198.

Munns, R. 2002. Comparative physiology of salt and water stress. Plant Cell Environ. 25:239250 .

Neto, J.F.B., N.D.E.M. Beltrao, J.P.G. Rigon, and S. Capuani. 2012. Effect of calcium and magnesium silicate on the growth of the castor oil plant subjected to salinity levels. Semina: Ciências Agrárias. Landrina 33(1):2949-2958.

Niu, G., S. Rodriguez, and T. Starman. 2010. Response of bedding plants to saline water irrigation. HortScience 45:628-636.

Stamps, R.H. and M.R. Evans. 1997. Growth of Dieffenbachia maculata 'Camille' in growing media containing sphagnum peat or coconut coir dust. HortScience 32:844-874.

Strefeler, M. 1991. A Brief overview of various closed irrigation systems and other methods of reducing contaminated runoff from greenhouses. Minnesota Flower Growers Bulletin 40(3).

Takemura, T., N. Hanagata, K. Sugihara, S. Baba, I. Karube, and Z. Dubinski. 2000. Physiological and biochemical responses to salt stress in the mangrove, Bruguiera gymnorrhiza. Aquatic Botany, Philadelphia 68 (1):15-28.

van Iersel, M.W. 2000. Postproduction leaching affects the growing medium and respiration of subirrigated Poinsettias. HortScience 35:250253.

Villarino, H., Mattson, S., 2011. Assessing tolerance to sodium chloride salinity in fourteen floriculture species. HortTechnology 21:539545 .

Vinocur, B. and A. Altman. 2005. Recent advances in engineering plant tolerance to abiotic stress: Achievement and limitations. Curr. Opin. Biotechnol. 16:123-132. 